\title{
Seasonal variation of microbial populations and biomass in Tatachia grassland soils of Taiwan
}

\author{
Shine-Tsern Cho - Shu-Hsien Tsai - Anita Ravindran • \\ Ammaiyappan Selvam $\cdot$ Shang-Shyng Yang
}

Received: 8 July 2006/Accepted: 5 July 2007 / Published online: 22 August 2007

(C) Springer Science+Business Media B.V. 2007

\begin{abstract}
To investigate the seasonal variations of microbial ecology in grassland of Tatachia forest, soil properties, microbial populations, microbial biomass, and $16 \mathrm{~S}$ rDNA clone library analysis were determined. The soil had temperatures $6.6-18.4^{\circ} \mathrm{C}, \mathrm{pH}$ 3.6-5.1, total organic carbon 1.11-10.68\%, total nitrogen $0.18-0.78 \%$, and $\mathrm{C} / \mathrm{N}$ ratios $3.46-20.55$. Each gram of dry soil contained bacteria, actinomycetes, fungi, cellulolytic, phosphate-solubilizing microbes, and nitrogen-fixing microbes $4.54 \times 10^{4}$ to $3.79 \times 10^{7}, 3.43 \times 10^{2}$ to $2.17 \times 10^{5}, 5.74 \times 10^{3}$ to $3.76 \times 10^{6}, 1.97 \times 10^{3}$ to $1.34 \times 10^{6}, 8.49 \times 10^{2}$ to $5.59 \times 10^{5}$, and $3.86 \times 10^{2}$ to $3.75 \times 10^{5} \mathrm{CFU}$, respectively. Each gram of soil contained 117$2,482 \mu \mathrm{g}$ of microbial biomass carbon, $23-216 \mu \mathrm{g}$ of microbial biomass nitrogen and 9-29 $\mu \mathrm{g}$ of DNA. The microbial populations, microbial biomass, and DNA decreased stepwise with the depth of soil, and they had low values in winter seasons. The microbial populations, microbial biomass carbon, microbial biomass nitrogen, and DNA at the BW2 horizon were $8.42-17.84,19.26-64.40,16.84-61.11$, and
\end{abstract}

S.-T. Cho · S.-H. Tsai · A. Ravindran .

A. Selvam · S.-S. Yang $(\bowtie)$

Institute of Microbiology and Biochemistry,

National Taiwan University, Taipei 10617, Taiwan

e-mail: ssyang@ntu.edu.tw

\section{S.-S. Yang}

Department of Biochemical Science and Technology,

National Taiwan University, Taipei 10617, Taiwan
$31.03-46.26 \%$ of those at the O horizon, respectively. When analyzing 16S rDNA library, members of Proteobacteria, Acidobacteria, Actinobacteria, Bacteroidetes, Chloroflexi, Firmicutes, candidate division TM1, candidate division TM7, Gammatimonadetes, and Verrucomicrobia were identified. Members of Proteobacteria (44.4\%) and Acidobacteria (33.3\%) dominated the clone libraries. Within the phylum Proteobacteria, $\alpha-, \beta$-, and $\gamma$-Proteobacteria were most numerous, followed by $\delta$-Proteobacteria.

Keywords Grassland - Microbial biomass carbon and nitrogen - Microbial ecology · Profile .

Seasonal variation $\cdot$ PCR $\cdot 16 \mathrm{~S}$ rDNA clone library

\section{Introduction}

Forest soil microorganisms and fauna strongly influence the nutrient cycling of ecosystem through regulating the dynamics of organic matter decomposition and plant nutrient availability (Nannipieri et al. 2003). The numbers and species of microbes in soil vary instantly with environmental conditions, nutrient availability, soil texture, and type of vegetation cover (Hedlund 2002; Allen and Schlesinger 2004). Forest soils have very high diversity of prokaryotes compared with other habitats (Torsvik et al. 1996). The complex structure of soil results in the isolation of organisms and partitioning of resources at different substructures of the soil environment, and in relation 
to gradients of soil chemical properties and microenvironments (Zhou et al. 2002; Treves et al. 2003). For microorganisms, local species richness is tightly linked to regional (and even global) species richness, and the environment simply selects which organisms are active (Finlay 2002). The diversity of soil microorganisms is high; it is less clear how that diversity relates to the functioning of grassland ecosystems.

In Taiwan, the microbial distributions of soils had only been determined in acidic soil of Yang-MingSan, inorganic acidic soil, upland soil, alkaline soil of Tainan and power plant areas (Yang et al. 1998b, 1999; Yang and Yang 2001). There are few data in the microbial populations of forest soils (Yang et al. 1998a, 2003, 2006; Imberger and Chiu 2001; Tsai et al. 2007). Tatachia mountain is located in the central part of Taiwan and is a typical high altitude ecosystem protected area, designated as a National Park. There are three major vegetations: grass, spruce, and hemlock in this temperate area. The present study aimed to use the parameters of microbial populations, biomass, and DNA as index of the environmental impacts in Tatachia grassland soils. To understand the diversity of bacteria in the grassland soil, three clone libraries of $16 \mathrm{~S}$ rDNA were constructed and the phylogenetic affiliation of these sequences is reported. The effects of season and depth on these parameters are also included in this article.

\section{Materials and methods}

\section{Site description}

The study was conducted at Tatachia, in the saddle of Jade Mountain, central Taiwan $\left(120^{\circ} 52^{\prime}\right.$ E, $\left.23^{\circ} 28^{\prime} \mathrm{N}\right)$. Tatachia has an elevation from 1,800 to $3,952 \mathrm{~m}$. Some environmental conditions and properties of the tested soils are listed in Fig. 1. The area has been selected as a representative long-term ecological study site of sub-alpine forest ecosystems in Taiwan. The study area consists geologically of metamorphosed sedimentary rock (Miocene epoch), comprising sandstone and shale. Dwarf bamboo (Yushania niitakayamensis) and alpine silver grass (Miscanthus transmorrisonensis) are the dominant vegetation. The annual precipitation of Tatachia grassland was between 2,800 and $3,000 \mathrm{~mm}$.
Soil sampling

Soil samples were collected at Tatachia grassland in organic layer, topsoil (0-20 cm depth) and subsoil (21-40 cm depth). The samples were sieved to $2 \mathrm{~mm}$, homogenized, and stored at $4^{\circ} \mathrm{C}$ for further studies. Soil DNA was extracted immediately when the soils were received in the laboratory.

\section{Cultural media and conditions}

Bacteria were counted at $25^{\circ} \mathrm{C}$ for 5 days on nutrient agar at $\mathrm{pH} 6.8 \pm 0.1$. Actinomycetes were cultivated at $25^{\circ} \mathrm{C}$ for 7 days on glycerol-yeast extract medium at $\mathrm{pH} 7.0 \pm 0.1$. Streptomycin and cycloheximide were added to inhibit the growth of bacteria and fungi at a final concentration of $10 \mu \mathrm{g} / \mathrm{ml}$ (Yang and Yang 2001). Fungi were grown at $25^{\circ} \mathrm{C}$ for 5 days on Rose Bengal medium at pH $6.8 \pm 0.1$ (Yang et al. 1998a). Cellulolytic microbes were assayed at $25^{\circ} \mathrm{C}$ after 7 days incubation on Mandels-Reese medium with carboxymethylcellulose (CMC, Sigma) as the sole carbon source and sprayed with Congo red to show a clear zone around the colonies (Mandels et al. 1981). Phosphate-solubilizing microbes were counted at $25^{\circ} \mathrm{C}$ after 5 days on rock phosphate medium at $\mathrm{pH}$ $6.6 \pm 0.1$ by the clear zone around the colonies (Chang et al. 2001). Nitrogen-fixing microbes were characterized at $25^{\circ} \mathrm{C}$ after 7 days incubation on nitrogen-free mannitol medium (Yang et al. 2003). All the experiments were carried out in triplicates.

Microbial biomass carbon and nitrogen

Microbial biomass carbon and nitrogen were determined by the chloroform fumigation extraction method (Brookes et al. 1985; Vance et al. 1987). Fresh soils at $40 \%$ water-holding capacity were fumigated with chloroform (ethanol removed) for $72 \mathrm{~h}$. A non-fumigated incubation (without chloroform) was conducted as the control. Soil extracts $8.0 \mathrm{ml}$ and $0.066 \mathrm{M} \mathrm{K}_{2} \mathrm{Cr}_{2} \mathrm{O}_{7} 2 \mathrm{ml}, \mathrm{HgO} 70 \mathrm{mg}$, conc. $\mathrm{H}_{2} \mathrm{SO}_{4} 10.0 \mathrm{ml}$ and $85 \% \mathrm{H}_{3} \mathrm{PO}_{4} 5.0 \mathrm{ml}$ were mixed thoroughly. The mixture was digested at $150^{\circ} \mathrm{C}$ for $30 \mathrm{~min}$, and titrated against $0.033 \mathrm{M}$ ferrous (II) ammonium sulfate using 1,10-phenanthroline-ferrous sulfate mixture as an indicator. For microbial biomass 
Fig. 1 Properties of grassland soil in Tatachia.

(a) Environmental conditions, (b) $\mathrm{pH}$, (c) Moisture content, (d) Total organic carbon (TOC),

(e) Total nitrogen $(\mathrm{TN}),(\mathbf{f})$

$\mathrm{C} / \mathrm{N}$ ratio. $\mathbf{a i r}$

temperature, $\square$ soil

temperature, $\bullet$ light intensity. organic layer, $\bigcirc$ topsoil, $\nabla$ subsoil.

Vertical bars represent standard deviations $(n=9)$

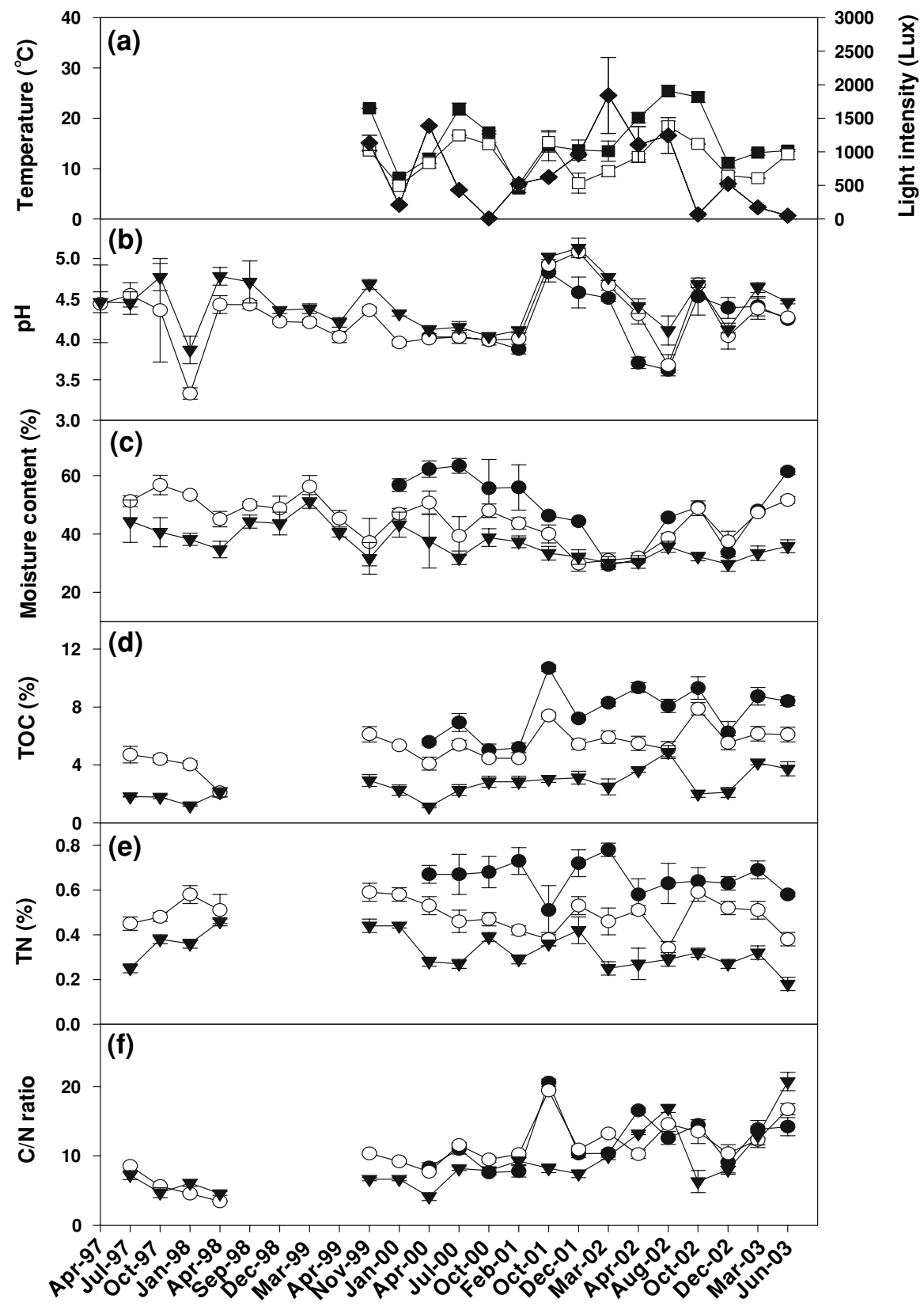

Sampling month \& year

nitrogen, the digested filtrate was distilled by steam distillation with a modified Kjeldahl method (Yang et al. 1991), and titrated against $0.01 \mathrm{~N} \mathrm{HCl}$. Microbial biomass carbon $\left(B_{\mathrm{C}}\right)$ was calculated according to the equation: $B_{\mathrm{C}}=E_{\mathrm{C}} / K_{\mathrm{EC}}$, where $E_{\mathrm{C}}$ is the difference between extractable $\mathrm{C}$ from fumigated and nonfumigated samples and $K_{\mathrm{EC}}=0.45$ (Wu et al. 1990). The microbial biomass nitrogen $\left(B_{\mathrm{N}}\right)$ was calculated as $B_{\mathrm{N}}=E_{\mathrm{N}} / K_{\mathrm{EN}}$, where $E_{\mathrm{N}}$ is the difference between extractable $\mathrm{N}$ from fumigated and non-fumigated samples and $K_{\mathrm{EN}}=0.54$ (Brookes et al. 1985).

\section{DNA extraction}

Genomic DNA of the soil was extracted following a modified protocol of Krsek and Wellington (1999). Soil 
DNA was extracted with Crombach buffer containing proteinase $\mathrm{K}$ at $37^{\circ} \mathrm{C}$ for $30 \mathrm{~min}$. Sodium dodecyl sulfate (SDS) was added and the samples were incubated at $65^{\circ} \mathrm{C}$ for $120 \mathrm{~min}$. The supernatant was collected after centrifugation at $4,500 \times g$ for $5 \mathrm{~min}$. Extraction was repeated twice using extraction buffer and 20\% SDS, and incubated at $65^{\circ} \mathrm{C}$ for $10 \mathrm{~min}$. After centrifugation, supernatants were subjected to potassium acetate and polyethyleneglycol precipitation, phenol/chloroform/ iso-amylalcohol purification, isopropanol precipitation, and spermine- $\mathrm{HCl}$ precipitation. The crude DNA was purified by Gene-Spin ${ }^{\mathrm{TM}}$ 1-4-3 DNA Extraction Kit (Protech Technology Enterprise Ltd, Taiwan) and stored at $-20^{\circ} \mathrm{C}$.

Effect of soil profile on microbial populations, biomass, and DNA

Soil profiles were taken from the grassland and classified into horizons according to the International Soil Classification System (Soil Survey Staff 2003). Soil samples were collected in each horizon from the top of soil to $100 \mathrm{~cm}$ depth. The microbial populations, biomass, and DNA at each horizon were measured.

\section{PCR amplification of 16S rDNA}

Bacterial 16S rDNAs were amplified by PCR using the primers $10 \mathrm{f}\left(5^{\prime}\right.$-AGTTT GATCCTGGCTCAG-3') and $1507 \mathrm{r}$ (5'-TACCTTGTTACGACTTCACCCCA$\left.3^{\prime}\right)$. Escherichia coli numbering positions of the primers are 10-27 and 1507-1485, respectively (Heyndrickx et al. 1996). The $50 \mu \mathrm{l}$ reaction solution containing $25 \mathrm{pmol}$ of each primer, $200 \mu \mathrm{M}$ of each dNTPs, $1 \times$ PCR buffer (Protech, with $\mathrm{MgCl}_{2}$ ), and 1.5 U Pro Taq DNA polymerase was combined with $1 \mu \mathrm{l}$ DNA. The PCR was performed with a Applied Biosystems 2720 Thermal Cycler (Foster City, CA, USA) with the following reaction conditions: $94^{\circ} \mathrm{C}$ for $5 \mathrm{~min}$, followed by 35 cycles at $95^{\circ} \mathrm{C}$ for $1 \mathrm{~min}$, $55^{\circ} \mathrm{C}$ for $30 \mathrm{~s}, 72^{\circ} \mathrm{C}$ for $1 \mathrm{~min}$, and a final extension step at $72^{\circ} \mathrm{C}$ for $10 \mathrm{~min}$. The PCR products were examined by electrophoresis on $1 \times$ TAE agarose gel $(2.0 \% \mathrm{w} / \mathrm{v})$ with $100 \mathrm{bp}$ DNA ladder (Promega, Madison, WI, USA) as marker to confirm the size and the approximate quantity of generated amplicons.
Construction and analysis of clone libraries

The PCR products of $16 \mathrm{~S}$ rRNA genes were completely loaded onto a $2 \%$ low melting agarose gel. The band with expected size of approximately $1.5 \mathrm{~kb}$ was cut and purified with a Gel Extraction Kit (Qiagen, CA, USA), and subsequently ligated into pGEM-T Vector Systems (Promega). The ligation product was transformed into competent E. coli JM109 cells and the clones were isolated by bluewhite screening with IPTG (isopropyl- $\beta$-D-thiogalactopyranoside) and X-Gal (5-bromo-4-chloro3 -indolyl- $\beta$-D-galacto-pyranoside). White colonies were plated on LB agar containing $100 \mu \mathrm{g} / \mathrm{ml}$ ampicillin. Approximately 40 clones were randomly selected to represent each of three composite forest soil samples.

Sequencing and phylogenetic analysis

The 120 transformants were sequenced (Mission Biotech., Taiwan) using the primer SP6, and 45 unique bacterial sequences were obtained. The close relatives and phylogenetic affiliation of the sequences obtained were checked using the BLAST search program at the National Center for Biotechnology Information (NCBI) website ( http://www.ncbi.nlm.nih.gov/). Sequences were also submitted to the Chimera Check program of RDP for checking the chimeric artifacts.

\section{Chemical analysis}

Moisture content was determined by drying the sample at $105^{\circ} \mathrm{C}$ overnight to a constant weight. The $\mathrm{pH}$ was measured in 5 times volume of distilled water equilibrated with soil for $1 \mathrm{~h}$ with a $\mathrm{pH}$ meter. Air and soil temperatures were determined on site directly or under $5 \mathrm{~cm}$ depth of soil with a thermometer. Total nitrogen was measured by a modified Kjeldahl method (Yang et al. 1991). Total organic carbon was determined as Nelson and Sommers (1982) described. Experiments were carried out in triplicates and statistical analysis of the results was performed using analysis of variance and Duncan's multiple range tests $(p=.05)$ with the help of the Statistical Analysis System (SAS Institute 2002). 


\section{Results}

Environmental conditions

Annual average air temperature is around $12^{\circ} \mathrm{C}$, and most months have cool weather. During the test period, January and February had low temperature $\left(6.0-8.3^{\circ} \mathrm{C}\right)$, while August and October had high temperature $\left(24.2-25.4^{\circ} \mathrm{C}\right)$ (Fig. 1). The soil temperature in winter seasons $\left(6.6-8.6^{\circ} \mathrm{C}\right)$ was higher than those of air temperature and it was reverse in summer seasons $\left(12.8-18.4^{\circ} \mathrm{C}\right)$ due to the high heat capacity of soil. The soil temperature is one of the major factors, that affects the microbial populations and the nutrient cycling in grassland soils.

\section{Soil properties}

The grassland soils of Tatachia is sandy loam and acidic. The $\mathrm{pH}$ of organic layer was the lowest, topsoil was the next, and subsoil was the highest (Fig. 1). The moisture content, total organic carbon and total nitrogen of organic layer were the highest, while subsoil was the lowest. The $\mathrm{C} / \mathrm{N}$ ratios of organic layer, topsoil, and subsoil were 7.62-20.55, 3.46-19.42, and 4.14-20.72, respectively.

\section{Bacterial populations}

The bacterial populations of grassland soils ranged from $(1.29 \pm 0.31) \times 10^{6}$ to $(3.79 \times 1.01) \times 10^{7} \mathrm{CFU} / \mathrm{g}$ organic layer, from $(1.31 \pm 1.05) \times 10^{5}$ to $(6.02 \pm 2.14)$ $\times 10^{6} \mathrm{CFU} / \mathrm{g}$ topsoil and from $(4.54 \pm 0.18) \times 10^{4}$ to $(5.32 \pm 0.91) \times 10^{6} \mathrm{CFU} / g$ subsoil (Fig. 2a). Most of organic layer and topsoil samples had higher bacterial populations than those of subsoil. The bacterial populations in summer seasons (July-September) were usually higher values than those in winter seasons (December-February). Statistical analysis revealed that $45.4 \%$ of the samples exhibited significant differences between topsoil and subsoil.

\section{Actinomycete populations}

Actinomycetes are known to have a diverse set of enzymes to degrade complex compounds for energy and biomass production. Actinomycete populations were between $(1.48 \pm 0.54) \times 10^{3}$ and $(2.17 \pm 0.56)$ $\times 10^{5} \mathrm{CFU} / \mathrm{g}$ organic layer, between $(2.38 \pm 0.83)$ $\times 10^{2}$ and $(1.26 \pm 0.13) \times 10^{5} \mathrm{CFU} / \mathrm{g}$ topsoil and between $(3.43 \pm 1.01) \times 10^{2}$ and $(7.93 \pm 0.41)$ $\times 10^{4} \mathrm{CFU} / \mathrm{g}$ subsoil (Fig. 2b). Organic layer and topsoil samples had higher populations than those of subsoil. All tested soils in summer seasons had higher values than those in winter seasons. From the statistical analysis, it was also found that $36.9 \%$ of actinomycete populations had significant differences between topsoil and subsoil samples.

\section{Fungal populations}

The $\mathrm{pH}$ of grassland soil was acidic, which is favorable for fungal propagation. The fungal populations were high in summer seasons $[(1.02 \pm 0.45)$ $\left.\times 10^{4}-(4.49 \pm 1.11) \times 10^{5} \mathrm{CFU} / \mathrm{g}\right]$ and low in winter seasons $\quad\left[(5.98 \pm 0.17) \times 10^{3}-(6.82 \pm 0.72) \times 10^{5}\right.$ CFU/g] (Fig. 2c). The populations were also high in organic layer and topsoil. From the statistical analysis, it showed that $45.5 \%$ of topsoil samples had significantly higher populations than those in subsoil.

Cellulolytic, phosphate-solubilizing, and nitrogen-fixing microbes

Cellulolytic, phosphate-solubilizing, and nitrogenfixing microbes are very important in elemental cycle and in plant nutrition of grassland soils. The populations varied with sampling season and soil depth. Each gram contained $(6.94 \pm 0.13) \times 10^{4}-(1.34 \pm 0.41)$ $\times 10^{6},(1.56 \pm 0.55) \times 10^{4}-(7.32 \pm 0.46) \times 10^{5}$ and $(1.97 \pm 0.32) \times 10^{3}-(1.17 \pm 0.41) \times 10^{5}$ CFU cellulolytic microbes in the organic layer, topsoil, and subsoil, respectively (Fig. 2d). The organic layer and topsoil had higher populations than those of the subsoil. Around $53.23 \%$ and $45.47 \%$ of the samples had significant differences between organic layer and topsoil, and between topsoil and subsoil, respectively. Although the populations of cellulolytic microbes varied at different seasons, the percentage of cellulolytic microbes in total microbial count was very consistent. The percentage was high in topsoil and low in organic layer. The values were 0.46 to $45.81 \%$ (average $9.05 \%$ ), 0.26 to $87.5 \%$ (average 19.75\%) 
Fig. 2 Seasonal variation of microbial populations in grassland soil of Tatachia. (a) Bacteria, (b)

Actinomycetes, (c) Fungi, (d) Cellulolytic microbes, (e) Phosphate-solubilizing microbes, (f) Nitrogenfixing microbes. organic layer, $\bigcirc$ topsoil, $\nabla$ subsoil. Vertical bars represent standard deviations $(n=9)$

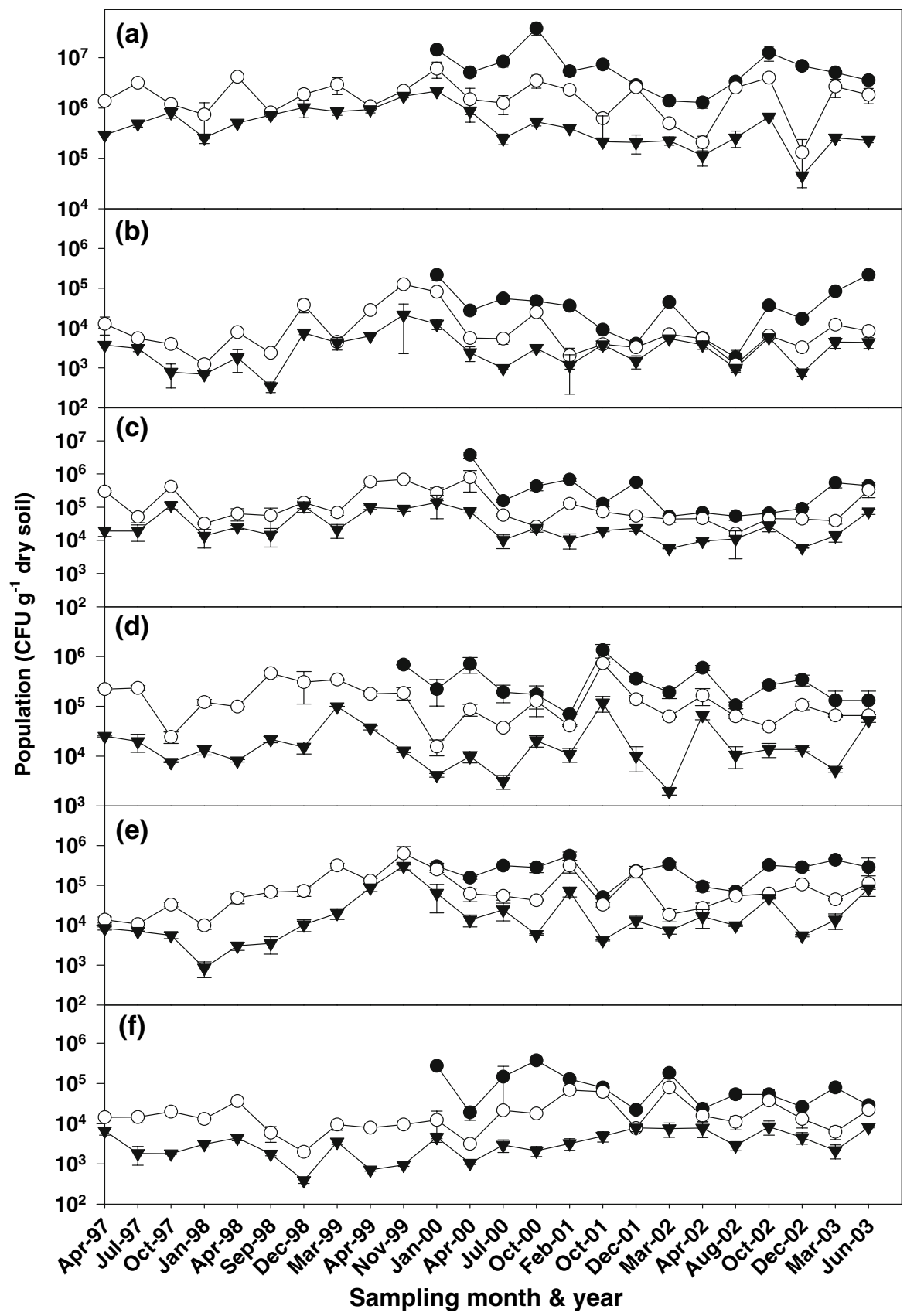

and 0.19 to $58.51 \%$ (average $9.46 \%$ ) in organic layer, topsoil, and subsoil, respectively. Whereas the percentages of cellulolytic microbes were also high in summer seasons (from 2.47 to $7.37 \%$, average $4.09 \%$ ) and low in winter seasons (from 5.35 to $80.92 \%$, average $20.18 \%$ ).

Each gram of soil had $(5.08 \pm 0.49) \times 10^{4}$ to $(5.59 \pm 1.32) \times 10^{5},(9.87 \pm 2.05) \times 10^{3}$ to $(6.38 \pm$
$0.94) \times 10^{5}$ and $(8.49 \pm 3.63) \times 10^{2}$ to $(3.08 \pm$ $0.61) \times 10^{5} \mathrm{CFU}$ phosphate-solubilizing microbes in the organic layer, topsoil, and subsoil, respectively (Fig. 2e). Most of the organic layer samples had the highest populations in all tested samples, and the seasonal variation was statistically significant. The percentage of phosphate-solubilizing microbes in total count ranged from 0.69 to $24.71 \%$ (average 
$6.18 \%$ ) in organic layer, from 1.17 to $80.92 \%$ (average 9.27\%) in topsoil and from 0.11 to $70.93 \%$ (average $11.24 \%$ ) in subsoil.

Each gram of soil contained $(1.92 \pm 0.71) \times 10^{4}$ to $(3.75 \pm 0.62) \times 10^{5}, \quad(1.98 \pm 0.19) \times 10^{3} \quad$ to $(7.93 \pm 0.39) \times 10^{4}$, and $(3.86 \pm 0.59) \times 10^{2}$ to $(8.38 \pm 3.23) \times 10^{3} \mathrm{CFU}$ nitrogen-fixing microbes in the organic layer, topsoil, and subsoil, respectively (Fig. 2f). From the statistical analysis, 38.35 and $50.24 \%$ of topsoil had significantly higher populations than those of organic layer and subsoil, respectively. The percentages of nitrogen-fixing microbes in total count ranged from 0.39 to $13.19 \%$ (average $2.08 \%$ ), from 0.11 to $16.09 \%$ (average $2.53 \%$ ), and from 0.04 to $10.00 \%$ (average $1.72 \%$ ) in the organic layer, topsoil, and subsoil, respectively. The percentages in organic layer were significantly lower than that in topsoil or subsoil. The populations and percentages were also higher in summer seasons than in winter seasons.

Microbial biomass carbon and nitrogen

The microbial biomass carbon and nitrogen contents in the organic layer, topsoil, and subsoil are illustrated in Table 1. Organic layer had the highest microbial biomass carbon and nitrogen, followed by topsoil, and subsoil was the least. Summer seasons had high microbial biomass carbon and nitrogen.

\section{DNA yield and purity}

DNA yield and purity of grassland soils are shown in Fig. 3. Organic layer had the highest yield of DNA $(21.5 \pm 2.2$ to $29.1 \pm 2.5 \mu \mathrm{g} / \mathrm{g})$ with the highest levels of humate and protein contamination in the three tested layers, followed by topsoil $(14.0 \pm 0.7$ to $17.7 \pm 0.6 \mu \mathrm{g} / \mathrm{g})$, while subsoil had the lowest $(8.6 \pm 0.2$ to $12.2 \pm 0.2 \mu \mathrm{g} / \mathrm{g})$. However, subsoil had the highest purity of DNA with the highest ratios of $\mathrm{A}_{260} / \mathrm{A}_{280}(1.35 \pm 0.11$ to $1.77 \pm 0.09)$ and $\mathrm{A}_{260} /$ $\mathrm{A}_{230}(1.35 \pm 0.18$ to $1.49 \pm 0.09)$, while organic layer had the lowest ratios of $\mathrm{A}_{260} / \mathrm{A}_{280}(1.02 \pm 0.07$ to $1.24 \pm 0.14)$ and $\mathrm{A}_{260} / \mathrm{A}_{230} \quad(0.94 \pm 0.28$ to $1.18 \pm 0.06)$. DNA yield and humic acid contamination varied significantly with soil depths, and the molecular size of obtained DNA was higher than $20 \mathrm{~kb}$.

Effect of soil depth on microbial population, microbial biomass, and DNA yield

The soil properties, microbial biomass, and DNA yield at various horizons of grassland soils are shown in Figs. 4 and 5. The soil pH increased slightly with depth, and had the highest $\mathrm{pH}$ at the BW2 horizon. The moisture content, total organic carbon, total nitrogen, microbial populations, microbial biomass carbon and nitrogen decreased gradually with increasing depth. The bacteria, actinomycetes, fungi, cellulolytic, phosphate-solubilizing, and nitrogenfixing microbes at the BW2 horizon were only $12.23,8.42,14.13,16.14,17.84$, and $16.87 \%$ of those at the $\mathrm{O}$ horizon, respectively. The microbial biomass carbon and nitrogen decreased from $180.71 \pm 18.25$ to $780.12 \pm 20.45 \mu \mathrm{g} \quad \mathrm{C} / \mathrm{g}$ and $50.06 \pm 5.25$ to $283.47 \pm 26.96 \mu \mathrm{g} \mathrm{N} / \mathrm{g}$ at the $\mathrm{O}$ horizon to $58.19 \pm 4.62-250.36 \pm 11.06 \mu \mathrm{g} \mathrm{C} / \mathrm{g}$ and $15.21 \pm 1.04-104.92 \pm 8.38 \mu \mathrm{g} \mathrm{N} / \mathrm{g}$ at the BW2 horizon, respectively. DNA yields and purity at different horizons of grassland are shown in Table 2. The DNA yield decreased with soil depth. However, the purity of DNA indicated by $\mathrm{A}_{260} / \mathrm{A}_{280}$ and $\mathrm{A}_{260} /$ $\mathrm{A}_{230}$ ratios was the opposite.

Correlations between soil properties and microbial indicators

Correlations between physical, chemical, and biological properties of grassland soils are summarized in Table 3. Microbial biomass carbon and nitrogen had significant positive correlation with soil moisture content and significant negative correlation with soil $\mathrm{pH}$. Microbial biomass carbon and nitrogen also had positive correlation with microbial populations. Total organic carbon had significant positive correlation with bacteria and actinomycetes, and positive correlation with other microbial populations. DNA yield had significant positive correlation with moisture content, total organic carbon, and total nitrogen. The moisture content and $\mathrm{pH}$ seem to be the most important factors influencing the microbial ecology and biomass in Tatachia grassland ecosystem. 
Table 1 Microbial biomass carbon and nitrogen contents in grassland soil

\begin{tabular}{|c|c|c|c|c|c|c|}
\hline \multirow[t]{2}{*}{ Sampling date } & \multicolumn{2}{|l|}{ Organic layer } & \multicolumn{2}{|l|}{ Topsoil } & \multicolumn{2}{|l|}{ Subsoil } \\
\hline & $\begin{array}{l}\text { Biomass } \mathrm{C} \\
(\mu \mathrm{g} / \mathrm{g} \text { dry soil })\end{array}$ & Biomass N & Biomass C & Biomass N & Biomass C & Biomass $\mathrm{N}$ \\
\hline Jul. 23, 1997 & & & $823 \pm 104$ & $99 \pm 32$ & $483 \pm 89$ & $78 \pm 33$ \\
\hline Oct. 10,1997 & & & $734 \pm 98$ & $115 \pm 43$ & $361 \pm 78$ & $61 \pm 36$ \\
\hline Jan. 18, 1998 & & & $678 \pm 88$ & $128 \pm 43$ & $381 \pm 83$ & $59 \pm 29$ \\
\hline Apr. 30, 1998 & & & $646 \pm 68$ & $134 \pm 33$ & $371 \pm 83$ & $39 \pm 11$ \\
\hline Mar. 10, 1999 & & & $578 \pm 25$ & $94 \pm 25$ & $226 \pm 26$ & $32 \pm 3$ \\
\hline Jan. 5, 2000 & & & $443 \pm 53$ & $41 \pm 9$ & $117 \pm 35$ & $28 \pm 6$ \\
\hline Apr. 23, 2000 & $1,421 \pm 469$ & $118 \pm 30$ & $922 \pm 71$ & $52 \pm 11$ & $687 \pm 42$ & $30 \pm 4$ \\
\hline Jul. 15, 2000 & $2,482 \pm 616$ & $216 \pm 67$ & $931 \pm 92$ & $67 \pm 6$ & $716 \pm 28$ & $31 \pm 6$ \\
\hline Oct. 6, 2000 & $1,906 \pm 476$ & $172 \pm 48$ & $926 \pm 49$ & $74 \pm 10$ & $606 \pm 60$ & $48 \pm 8$ \\
\hline Feb. 1, 2001 & $1,253 \pm 270$ & $124 \pm 55$ & $827 \pm 81$ & $59 \pm 8$ & $513 \pm 60$ & $28 \pm 6$ \\
\hline Apr. 19, 2002 & $1,039 \pm 59$ & $129 \pm 28$ & $706 \pm 5$ & $96 \pm 5$ & $545 \pm 14$ & $53 \pm 1$ \\
\hline Aug. 14, 2002 & $1,146 \pm 54$ & $149 \pm 23$ & $822 \pm 43$ & $111 \pm 6$ & $578 \pm 15$ & $78 \pm 1$ \\
\hline Oct. 4, 2002 & $1,095 \pm 11$ & $120 \pm 29$ & $695 \pm 44$ & $87 \pm 2$ & $404 \pm 11$ & $70 \pm 1$ \\
\hline Dec. 17, 2002 & $818 \pm 11$ & $109 \pm 23$ & $678 \pm 62$ & $82 \pm 23$ & $235 \pm 12$ & $23 \pm 2$ \\
\hline Mar. 14, 2003 & $717 \pm 22$ & $122 \pm 13$ & $662 \pm 49$ & $95 \pm 6$ & $357 \pm 11$ & $45 \pm 2$ \\
\hline Jun. 10, 2003 & $899 \pm 72$ & $138 \pm 30$ & $876 \pm 26$ & $109 \pm 5$ & $416 \pm 12$ & $49 \pm 4$ \\
\hline
\end{tabular}

Means $\pm \operatorname{SD}(\mathrm{n}=3)$

Sequencing and phylogenetic analysis

Of the 120 clones analyzed by sequencing, 45 unique sequences were identified in the three clone libraries (Table 4). Clones were members of 10 bacterial phyla: Proteobacteria, Acidobacteria, Actinobacteria, Bacteroidetes, Chloroflexi, Firmicutes, candidate division TM1, candidate division TM7, Gammatimonadetes, and Verrucomicrobia. Members of Proteobacteria (44.4\%) and Acidobacteria (33.3\%) dominated the clone libraries. Within the phylum Proteobacteria, $\alpha-, \beta$-, and $\gamma$-Proteobacteria were most numerous, followed by $\delta$-Proteobacteria. Each of the remaining bacterial divisions constituted $<5 \%$ of the clone library.

\section{Discussion}

Tatachia mountain is located in the central part of Taiwan and is divided into three parts according to the vegetation, grassland, spruce, and hemlock. The $\mathrm{pH}$ of grassland soils was weakly acidic due to the leaf litter on the surface, the decomposition of leaf litter, and the accumulation of organic acids (Chen and Yang 2000). The subsoil exhibited higher $\mathrm{pH}$ values than those of the organic layer or topsoil because of the lower organic matter content, microbial activity and organic acid accumulation. The $\mathrm{pH}$ values were slightly lower in summer seasons than in winter seasons due to the high temperature in summer season for active microbial activity and organic acid accumulation. Berg et al. (1998) indicated that the Wekerom forest soil in the Netherlands had a soil pH of 3.8 for the high organic matter content. Yang and Yang (2001) also reported that the nuclear and thermal power plants in northern Taiwan had soil $\mathrm{pH}$ ranging from 4.34 to 4.47 because of the organic matter covering the surface and the inceptisol.

In the spruce and hemlock soils of Tatachia, the $\mathrm{pH}$ value of organic layer was also the lowest, followed by topsoil, and subsoil was the highest. These ecosystems were characterized by the heavy leaf residue on surface and the accumulation of organic acids during leaf residue decomposition (Yang et al. 2003, 2006). The soil pH values of grassland were slightly higher than spruce or hemlock soils due to the less leaf deposit on the surface of grassland soils. 


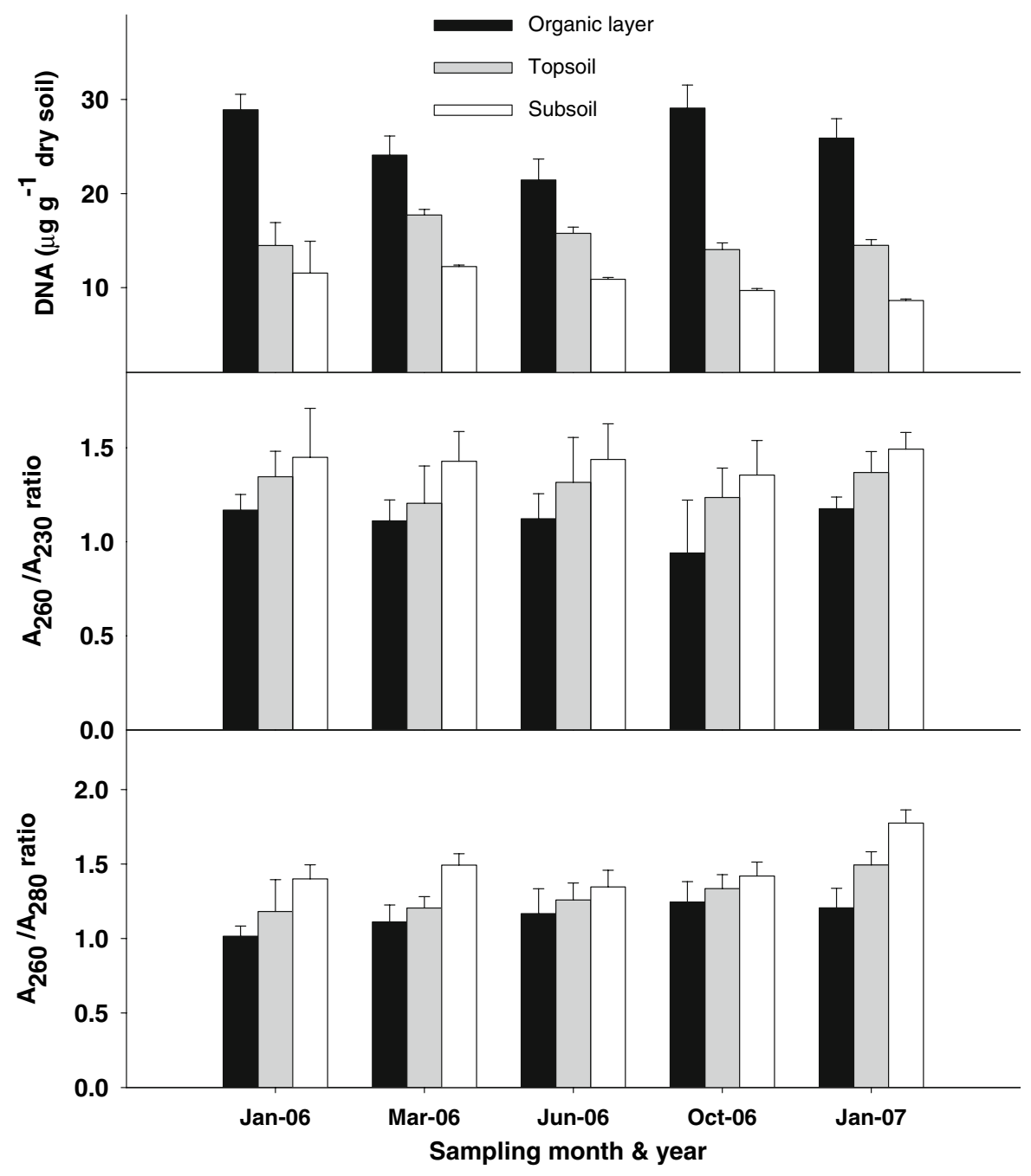

Fig. 3 DNA yield and purity of grassland soil. (a) DNA yield, (b) $\mathrm{A}_{260} / \mathrm{A}_{230}$ ratio, (c) $\mathrm{A}_{260} / \mathrm{A}_{280}$ ratio $(n=6)$

The soil moisture content depends on the environmental conditions. Seasonal variation of the moisture content in organic layer was higher than in the topsoil or subsoil due to the greater environmental change and the heavier organic matter covering. The soil moisture in summer seasons was also higher than in winter seasons, mainly attributable to the raining season during JulySeptember. Same phenomena were also found in power plant areas, spruce, and hemlock soils of Tatachia. The water-holding capacities of organic layer in grassland soils were higher than those of topsoil or subsoil because of the high organic matter content in the organic layer. The result is same as the spruce and hemlock forest soils of Tatachia (Yang et al. 2003, 2006).
Although the variation of culturable microbes was large during the tested periods, the microbial populations were low in subsoil due to the low total organic carbon, total nitrogen, moisture content, and comparatively less oxygen concentration. The microbial populations and microbial biomass were higher in summer seasons because of high soil temperature $\left(12.8-18.4^{\circ} \mathrm{C}\right.$ in summer seasons, and $6.6-8.6^{\circ} \mathrm{C}$ in winter seasons), which might favor the microbial activity. Srivastava and Singh (1988) showed that tropical soils had low carbon $(0.6 \%)$ and nitrogen $(0.01 \%)$ contents due to the dry condition and less vegetation. Fisk et al. (2003) reported that microbial activity of peat land was greater in surface than 


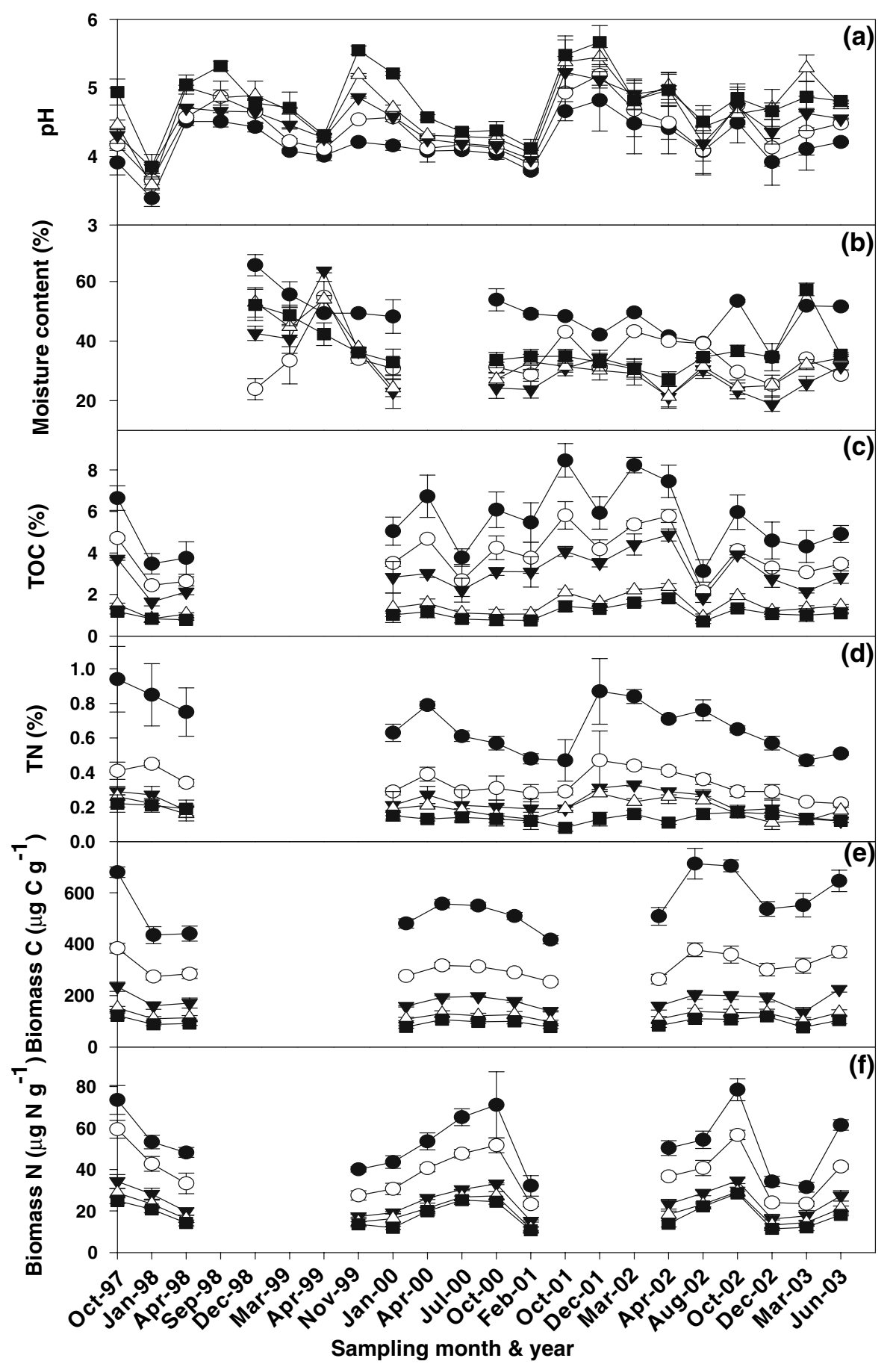

Fig. 4 Seasonal variation of soil properties at different horizons of grassland in Tatachia. (a) $\mathrm{pH}$, (b) Moisture content, (c) Total organic carbon (TOC), (d) Total nitrogen (TN), (e)

subsurface for the high organic matter content. Grassland soils had slightly lower total organic carbon and total nitrogen contents than those of spruce or
Microbial biomass carbon, (f) Microbial biomass nitrogen. O layer, $\bigcirc$ Oa layer, $\nabla$ A layer, $\nabla$ BW1 layer, $\mathbf{B W} 2$ layer. Vertical bars represent standard deviations $(n=6)$

hemlock soils. Therefore, the microbial populations of grassland soils were also lower than the other two forest ecosystems. Miethling et al. (2000) also 
Fig. 5 Seasonal variation of microbes at different horizons of grassland in Tatachia. (a) Bacteria, (b) Actinomycetes, (c) Fungi, (d) Cellulolytic microbes, (e) Phosphate-solubilizing microbes, (f) Nitrogenfixing microbes. O layer, $\bigcirc$ Oa layer, $\boldsymbol{\nabla}$ A layer, $\nabla$ BW1 layer, BW2 layer. Vertical bars represent standard deviations $(n=6)$

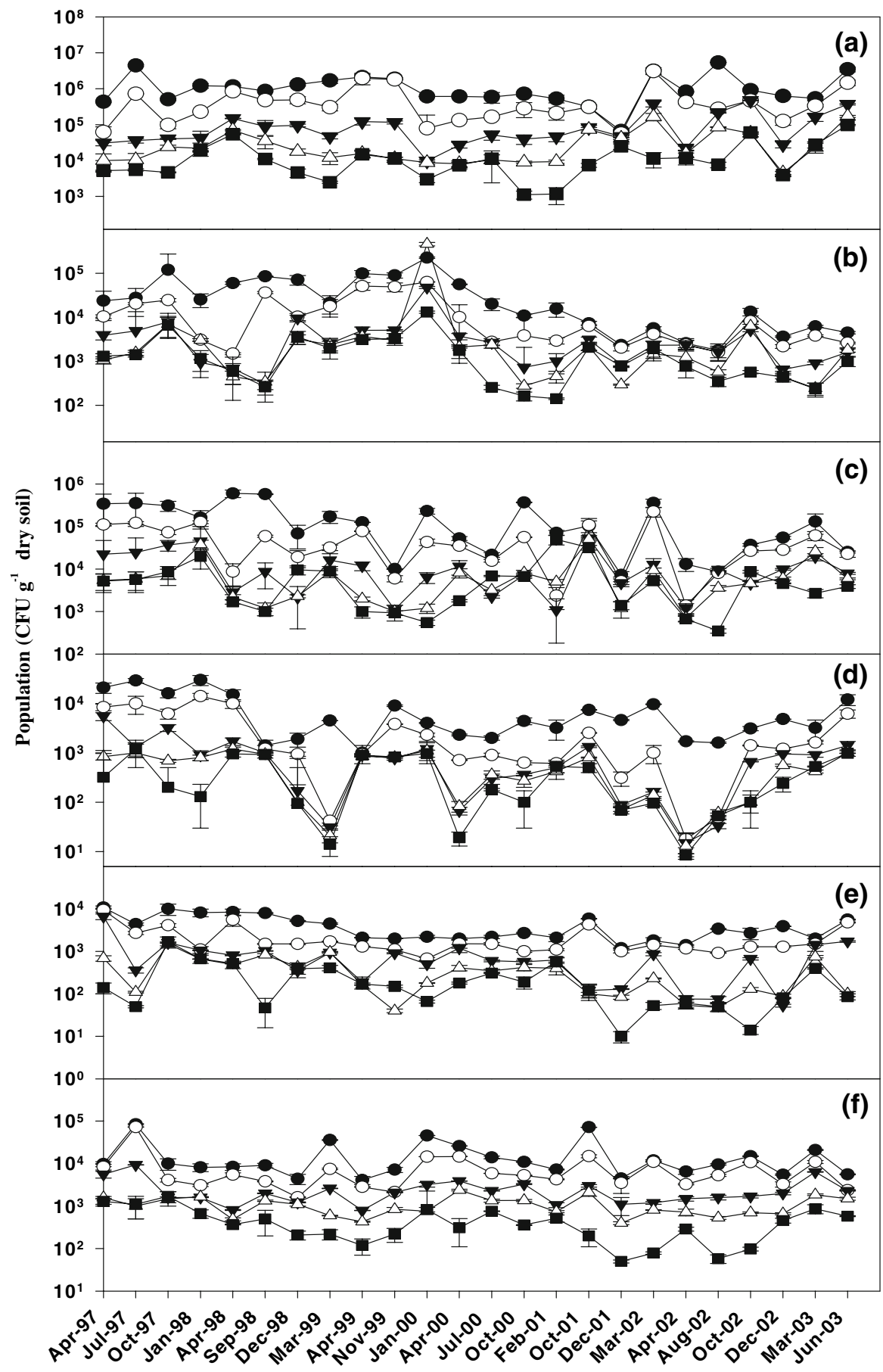

Sampling month \& year

showed that same soil type with different plant species affected the microbial populations. The microbial populations in subsoil were 11.05-96.51, 4.99-70.71, $1.74-82.50, \quad 1.54-74.88,2.11-89.26$, and 1.23$40.06 \%$ of bacteria, actinomycetes, fungi, cellulolytic, phosphate-solubilizing, and nitrogen-fixing microbes, respectively, as in organic layer. The percentages of microbial populations in subsoil of Tatachia spruce soils were $24.86-91.26,11.63-97.98,12.63-93.18$, $14.65-90.64,27.22-81.64$, and $24.86-74.55 \%$ as in 
Table 2 DNA yield and purity of grassland profile

\begin{tabular}{|c|c|c|c|c|c|}
\hline Sampling date & $\mathrm{O}$ & $\mathrm{Oa}$ & A & BW1 & BW2 \\
\hline \multicolumn{6}{|c|}{ (1) DNA yield ( $\mu g / g$ dry soil) } \\
\hline Jan. 14, 2006 & $29.0 \pm 2.3^{*}$ & $21.7 \pm 0.7$ & $17.2 \pm 1.0$ & $12.4 \pm 0.7$ & $9.0 \pm 0.3$ \\
\hline Mar. 26, 2006 & $31.6 \pm 1.5$ & $25.4 \pm 0.6$ & $17.9 \pm 2.1$ & $13.9 \pm 1.1$ & $11.9 \pm 1.6$ \\
\hline Jun. 27, 2006 & $28.1 \pm 1.6$ & $22.6 \pm 3.7$ & $22.6 \pm 1.2$ & $20.1 \pm 2.2$ & $13.0 \pm 3.7$ \\
\hline Oct. 1, 2006 & $25.0 \pm 2.8$ & $20.1 \pm 0.7$ & $17.9 \pm 3.3$ & $16.8 \pm 2.4$ & $10.5 \pm 1.9$ \\
\hline $\begin{array}{l}\text { Jan. } 12,2007 \\
\text { (2) } A_{260} / A_{230} r a\end{array}$ & $22.3 \pm 1.5$ & $17.9 \pm 3.6$ & $17.7 \pm 1.1$ & $13.9 \pm 1.3$ & $8.3 \pm 1.6$ \\
\hline Jan. 14, 2006 & $1.05 \pm 0.27$ & $1.24 \pm 0.22$ & $1.26 \pm 0.09$ & $1.46 \pm 0.17$ & $1.49 \pm 0.07$ \\
\hline Mar. 26, 2006 & $1.10 \pm 0.08$ & $1.24 \pm 0.22$ & $1.47 \pm 0.14$ & $1.53 \pm 0.22$ & $1.77 \pm 0.15$ \\
\hline Jun. 27, 2006 & $1.02 \pm 0.09$ & $1.14 \pm 0.27$ & $1.36 \pm 0.16$ & $1.48 \pm 0.26$ & $1.60 \pm 0.17$ \\
\hline Oct. 1, 2006 & $0.94 \pm 0.02$ & $1.05 \pm 0.10$ & $1.25 \pm 0.29$ & $1.64 \pm 0.24$ & $1.75 \pm 0.19$ \\
\hline $\begin{array}{l}\text { Jan. } 12,2007 \\
\text { (3) } A_{260} / A_{280} r a\end{array}$ & $1.17 \pm 0.04$ & $1.31 \pm 0.12$ & $1.56 \pm 0.08$ & $1.65 \pm 0.12$ & $1.79 \pm 0.08$ \\
\hline Jan. 14, 2006 & $1.01 \pm 0.09$ & $1.03 \pm 0.07$ & $1.04 \pm 0.12$ & $1.35 \pm 0.24$ & $1.32 \pm 0.33$ \\
\hline Mar. 26, 2006 & $1.07 \pm 0.10$ & $1.17 \pm 0.08$ & $1.31 \pm 0.09$ & $1.66 \pm 0.15$ & $1.83 \pm 0.12$ \\
\hline Jun. 27, 2006 & $1.22 \pm 0.14$ & $1.33 \pm 0.12$ & $1.50 \pm 0.13$ & $1.89 \pm 0.22$ & $1.97 \pm 0.17$ \\
\hline Oct. 1, 2006 & $1.24 \pm 0.14$ & $1.35 \pm 0.18$ & $1.51 \pm 0.11$ & $1.72 \pm 0.10$ & $1.79 \pm 0.12$ \\
\hline Jan. 12, 2007 & $1.13 \pm 0.11$ & $1.30 \pm 0.09$ & $1.34 \pm 0.10$ & $1.69 \pm 0.18$ & $1.70 \pm 0.14$ \\
\hline
\end{tabular}

* Mean \pm SD $(\mathrm{n}=3)$

Table 3 Correlations between physical, chemical, and biological properties of grassland soil

\begin{tabular}{|c|c|c|c|c|c|c|c|c|c|c|c|c|c|}
\hline Soil properties & A & B & $\mathrm{C}$ & $\mathrm{D}$ & $\mathrm{E}$ & $\mathrm{F}$ & G & $\mathrm{H}$ & I & $\mathbf{J}$ & $\mathrm{K}$ & $\mathrm{L}$ & M \\
\hline $\mathrm{pH}(\mathrm{A})$ & 1.000 & & & & & & & & & & & & \\
\hline MC (B) & -.332 & 1.000 & & & & & & & & & & & \\
\hline $\mathrm{C}_{\text {org }}(\mathrm{C})$ & .023 & .578 & 1.000 & & & & & & & & & & \\
\hline $\mathrm{N}_{\text {tot }}$ (D) & -.065 & .181 & .323 & 1.000 & & & & & & & & & \\
\hline $\mathrm{C} / \mathrm{N}(\mathrm{E})$ & .146 & .283 & .455 & .097 & 1.000 & & & & & & & & \\
\hline $\operatorname{Bac}(F)$ & -.177 & .279 & .502 & .082 & -.076 & 1.000 & & & & & & & \\
\hline Act $(G)$ & -.075 & .487 & .729 & .044 & .171 & .157 & 1.000 & & & & & & \\
\hline Fungi (H) & -.016 & .441 & .392 & .275 & .258 & .160 & .340 & 1.000 & & & & & \\
\hline CMC (I) & -.152 & .445 & .262 & .194 & .203 & .696 & .435 & .395 & 1.000 & & & & \\
\hline $\operatorname{PSB}(\mathrm{J})$ & -.117 & .296 & .178 & .163 & .084 & .092 & .214 & .522 & .424 & 1.000 & & & \\
\hline NFB (K) & -.161 & .467 & .348 & .282 & .276 & .046 & .238 & 683 & .343 & .793 & 1.000 & & \\
\hline $\mathrm{C}_{\text {mic }}(\mathrm{L})$ & -.690 & .680 & .120 & .118 & -.001 & .273 & .246 & .390 & .313 & .389 & .517 & 1.000 & \\
\hline $\mathrm{N}_{\text {mic }}(\mathrm{M})$ & -.607 & .641 & .302 & .150 & .183 & .220 & .373 & .445 & .339 & .333 & .493 & .862 & 1.000 \\
\hline DNA (N) & .033 & 690 & .659 & .705 & .369 & .409 & .065 & .246 & .019 & .039 & .190 & .427 & .401 \\
\hline
\end{tabular}

Linear regressions were used. $n>90$. MC: moisture content, $\mathrm{C}_{\text {org }}$ : total organic $\mathrm{C}$ content, $\mathrm{N}_{\text {tot }}$ : total $\mathrm{N}$ content, Bac: bacteria, Act: actinomycetes, CMC: cellulolytic microbes, PSB: phosphate-solubilizing microbes, NFB: nitrogen-fixing microbes, $\mathrm{C}_{\text {mic }}$ : soil microbial biomass $\mathrm{C}, \mathrm{N}_{\text {mic }}$ : soil microbial biomass $\mathrm{N}$; DNA: DNA yield

topsoil, respectively (Yang et al. 2003). Similarly, the percentages of hemlock soils in subsoil of Tatachia were $11.58-111.96,2.61-96.96,4.66-92.10,8.91-$ $55.56,16.82-66.44$, and $7.83-60.74 \%$ as in topsoil, respectively (Yang et al. 2006). The ranges of microbial populations in grassland soils were less than those of spruce and hemlock soils due to the stick soil structures for nutrition and water penetration from 
Table 4 Identification of bacterial strains in 16S rDNA clone library isolated from Tatachia grassland soil

\begin{tabular}{|c|c|c|c|c|}
\hline Name & $\begin{array}{l}\text { Closest related organism } \\
\text { in the database }\end{array}$ & $\begin{array}{l}\text { Accession number } \\
\text { of reference strain }\end{array}$ & Identity (\%) & Taxon \\
\hline TG1 & Acidobacteria bacterium Ellin7184 & AY673350 & 97 & Acidobacteria \\
\hline TG2 & Acidobacteriaceae bacterium KBS89 & AY587227 & 97 & Acidobacteria \\
\hline TG3 & Bacterium Ellin6071 & AY234723 & 99 & Acidobacteria \\
\hline TG4 & $\begin{array}{l}\text { Uncultured Acidobacteria bacterium } \\
\text { FAC3 }\end{array}$ & DQ451442 & 98 & Acidobacteria \\
\hline TG5 & $\begin{array}{l}\text { Uncultured Acidobacteria bacterium } \\
\text { FAC8 }\end{array}$ & DQ451447 & 96 & Acidobacteria \\
\hline TG6 & $\begin{array}{l}\text { Uncultured Acidobacteria bacterium } \\
\text { FAC9 }\end{array}$ & DQ451448 & 96 & Acidobacteria \\
\hline TG7 & $\begin{array}{l}\text { Uncultured Acidobacteria bacterium } \\
\text { JG36-GS-69 }\end{array}$ & AJ582046 & 97 & Acidobacteria \\
\hline TG8 & $\begin{array}{l}\text { Uncultured Acidobacteriales bacterium } \\
\text { EB1134 }\end{array}$ & AY395453 & 98 & Acidobacteria \\
\hline TG9 & Uncultured Acidobacterium UA3 & AF200699 & 97 & Acidobacteria \\
\hline TG10 & Uncultured bacterium AH61 & AY963354 & 97 & Acidobacteria \\
\hline TG11 & Uncultured Holophaga sp. JG30-KF-C5 & AJ536863 & 96 & Acidobacteria \\
\hline TG12 & Uncultured Holophaga sp. JG37-AG-74 & AJ519380 & 97 & Acidobacteria \\
\hline TG13 & Bacterium Ellin504 & AY960767 & 98 & Acidobacteria \\
\hline TG14 & $\begin{array}{l}\text { Uncultured Acidobacteria bacterium } \\
\text { G08_WMSP1 }\end{array}$ & DQ450718 & 89 & Acidobacteria \\
\hline TG15 & $\begin{array}{l}\text { Uncultured Acidobacteria bacterium } \\
\text { JG36-GS-126 }\end{array}$ & AJ582044 & 97 & Acidobacteria \\
\hline TG16 & Alpha proteobacterium A0902 & AF236003 & 97 & Alphaproteobacteria \\
\hline TG17 & $\begin{array}{l}\text { Uncultured alpha proteobacterium } \\
\text { EB1127 }\end{array}$ & AY395446 & 97 & Alphaproteobacteria \\
\hline TG18 & $\begin{array}{l}\text { Uncultured alpha proteobacterium } \\
\text { JG37-AG-11 }\end{array}$ & AJ518764 & 98 & Alphaproteobacteria \\
\hline TG19 & Uncultured bacterium GKS2-215 & AJ 290032 & 94 & Alphaproteobacteria \\
\hline TG20 & Uncultured Bradyrhizobium sp. TM16_2 & DQ303345 & 99 & Alphaproteobacteria \\
\hline TG21 & Bacterium Ellin321 & AF498703 & 97 & Betaproteobacteria \\
\hline TG22 & Burkholderia sp. LMG 22929 RG3-1 & AY949190 & 98 & Betaproteobacteria \\
\hline TG23 & Ralstonia pickettii strain ATCC 27511 & AY741342 & 99 & Betaproteobacteria \\
\hline TG24 & Uncultured bacterium HSM-SS-006 & AB238769 & 98 & Betaproteobacteria \\
\hline TG25 & Uncultured beta proteobacterium B-BH93 & AY622261 & 99 & Betaproteobacteria, \\
\hline TG26 & Uncultured beta proteobacterium NE45 & AJ575695 & 98 & Betaproteobacteria \\
\hline TG27 & $\begin{array}{l}\text { Uncultured beta proteobacterium } \\
\text { JG36-GS-10 }\end{array}$ & AJ582037 & 95 & Betaproteobacteria \\
\hline TG28 & Frateuria aurantia strain:IFO13331 & AB091200 & 98 & Gammaproteobacteria \\
\hline TG29 & Frateuria sp. WJ64 & AY495957 & 99 & Gammaproteobacteria \\
\hline TG30 & Gamma proteobacterium RI-34-2 & AY539825 & 98 & Gammaproteobacteria \\
\hline TG31 & Lysobacter ginsengisoli strain:Gsoil 357 & AB245363 & 95 & Gammaproteobacteria \\
\hline TG32 & $\begin{array}{l}\text { Uncultured gamma proteobacterium } \\
\text { FAC23 }\end{array}$ & DQ451462 & 95 & Gammaproteobacteria \\
\hline TG33 & $\begin{array}{l}\text { Uncultured gamma proteobacterium } \\
\text { YNPRH65B }\end{array}$ & AF465652 & 97 & Gammaproteobacteria \\
\hline
\end{tabular}


Table 4 continued

\begin{tabular}{|c|c|c|c|c|}
\hline Name & $\begin{array}{l}\text { Closest related organism } \\
\text { in the database }\end{array}$ & $\begin{array}{l}\text { Accession number } \\
\text { of reference strain }\end{array}$ & Identity (\%) & Taxon \\
\hline TG34 & $\begin{array}{l}\text { Uncultured delta proteobacterium } \\
\text { JG37-AG-113 }\end{array}$ & AJ518798 & 95 & Deltaproteobacteria \\
\hline TG35 & Byssophaga cruenta DSM $14553 \mathrm{~T}$ & AJ833647 & 96 & Deltaproteobacteria \\
\hline TG36 & $\begin{array}{l}\text { Uncultured Actinomycetales bacterium } \\
\text { TM146 }\end{array}$ & X92699 & 98 & Actinobacteria \\
\hline TG37 & $\begin{array}{l}\text { Uncultured Actinomycetales bacterium } \\
\text { TM146 }\end{array}$ & X92699 & 94 & Actinobacteria \\
\hline TG38 & Cytophagales str. MBIC4147 & AB022889 & 95 & Bacteroidetes \\
\hline TG39 & $\begin{array}{l}\text { Uncultured Termite group } 1 \text { bacterium } \\
\text { S-J147 }\end{array}$ & AY622271 & 94 & candidate division TM1 \\
\hline TG40 & Uncultured bacterium NoosaAW16 & AF269015 & 93 & candidate division TM7 \\
\hline TG41 & Uncultured bacterium NoosaAW07 & AF269011 & 96 & candidate division TM7 \\
\hline TG42 & $\begin{array}{l}\text { Uncultured Chloroflexi bacterium } \\
\text { E11_WMSP1 }\end{array}$ & DQ450736 & 98 & Chloroflexi \\
\hline TG43 & Bacillaceae bacterium KVD-1790-02 & DQ490383 & 99 & Firmicutes \\
\hline TG44 & Gemmatimonadetes bacterium Ellin7146 & AY673312 & 99 & Gemmatimonadetes \\
\hline TG45 & Bacterium Ellin5102 & AY234519 & 98 & Verrucomicrobia \\
\hline
\end{tabular}

topsoil to subsoil. Similarly, the microbial populations in subsoil of power plant areas had only 19.20$71.62 \%$ of bacteria, $21.58-87.34 \%$ of actinomycetes, and $15.41-72.92 \%$ of fungi as those in topsoil due to the stickiness of tested soils (Yang and Yang 2001). Microbial biomass carbon and nitrogen, and DNA in subsoil of grassland were 26.41-77.20, 28.05-80.46, and $59.31-79.31 \%$ as those in topsoil, respectively. The microbial populations, microbial biomass and DNA of the BW2 horizon in grassland soils were $8.42-17.84,16.84-64.40$, and $31.03-46.26 \%$ of those at the $\mathrm{O}$ horizon, respectively. Similar phenomenon was also reported in other studies (Yang et al. 2003, 2006). The microbial activity, biomass, ATP content, respiration, and relative abundance of denitrifying and dinitrogen-fixing bacteria decreased with increasing depth in forest soils of southern Appalachian Mountains (Garten 2004). The bacterial populations and the mycelial content decreased with increasing depth in pine forest soils (Berg et al. 1998), and the nitrifying bacterial counts also decreased in acidic forest soils of Douglas (de Boer et al. 1992).

Although the populations of cellulolytic, phosphate-solubilizing, and nitrogen-fixing microbes varied with season and location, the ratios of these microbes to total viable counts could be used to assay the change of microbial ecology. The ratios of cellulolytic microbes to total viable counts were between 11.53 and $25.15 \%$ (average 20.53\%) in grassland soils. The value was lower than 41.84 $86.37 \%$ (average $63.74 \%$ ) in spruce, $8.91-94.42 \%$ (average 52.90\%) in hemlock, and 17.21-60.20\% (average $43.52 \%$ ) in nuclear and thermal power plant areas (Yang and Yang 2001; Yang et al. 2003, 2006) due to the less coverage of organic matter lying on the surface of grassland soils. Bradley and Fyles (1995) suggested that basal respiration was 2-3 times high in the active rhizosphere due to the high amount of root-labile $\mathrm{C}$ in this area. Tietema and Wessel (1994) also reported that microbes associated with oak leaf decomposition were very active in forest soils and essential for the elemental cycle and the nutritional supplement. The differences in the chemical composition of litters and root exudates would be expected to result in different availabilities of various carbon sources among stands of different tree species (Grayston et al. 1996). The ratios of phosphatesolubilizing microbes to total viable counts were $1.88-5.67 \%$ (average $3.78 \%$ ). The values were lower than nuclear and thermal power plants areas (2.11-40.75\%, average $22.26 \%$ ), spruce soils (7.11-21.30\%, average $12.00 \%$ ) and hemlock soils 
(6.82-66.48\%, average $25.75 \%)$ in Tatachia. In addition, the percentages of nitrogen-fixing microbes in total viable counts were between 2.83 and $7.26 \%$ (average 5.05\%). The values were also lower than hemlock soils $(2.20-51.77 \%$, average $19.32 \%)$, spruce soils (22.53-68.72\%, average $38.02 \%$ ) in Tatachia, and nuclear and thermal power plants areas (1.20-60.73\%, average 23.86\%) (Yang and Yang 2001; Yang et al. 2003, 2006). Both of these were due to less organic matter content on the surface of grassland soils.

Microbial biomass carbon of grassland soils (Table 1) was higher than that in tropical soils of India (149-667 $\mu \mathrm{g} \mathrm{C/g}$ dry soil) (Srivastava and Singh 1988), but lower than spruce soils (8932,801 $\mu \mathrm{g} \mathrm{C/g}$ organic layer, 644-2,018 $\mu \mathrm{g} \mathrm{C/g}$ topsoil and $438-832 \mu \mathrm{g} \mathrm{C/g}$ subsoil) and hemlock soils (678-2,801 $\mu \mathrm{g} \mathrm{C/g}$ organic layer, 355-1,013 $\mu \mathrm{g} \mathrm{C/g}$ in topsoil and 99-832 $\mu \mathrm{g} \mathrm{C/g}$ subsoil) (Yang et al. 2003, 2006) in Tatachia because of the low organic matter content in grassland soils.

Microbial biomass nitrogen of grassland soils (Table 1) was higher than those in tropical forest soils of India (38-78 $\mu \mathrm{g} \mathrm{N} / \mathrm{g}$ soil) (Raghubanshi 1991), slightly less than those of spruce soils (75$190 \mu \mathrm{g} \mathrm{N} / \mathrm{g}$ organic layer, 55-229 $\mu \mathrm{g} \mathrm{N} / \mathrm{g}$ topsoil, and 21-139 $\mu \mathrm{g} \mathrm{N} / \mathrm{g}$ subsoil) and hemlock soils (53$166 \mu \mathrm{g} \mathrm{N} / \mathrm{g}$ organic layer, 35-147 $\mu \mathrm{g} \mathrm{N} / \mathrm{g}$ topsoil, and 11-137 $\mu \mathrm{g}$ N/g subsoil) in Tatachia (Yang et al. 2003, 2006) and lower than forest soils in Germany (30-347 $\mu \mathrm{g} \mathrm{N/g}$ dry soil) (Joergensen et al. 1990). The microbial biomass carbon of pine and spruce forest soils in Finland was also higher in $0-3 \mathrm{~cm}$ depth of mineral soil than that in $0-6 \mathrm{~cm}$ depth of mineral soil (Priha et al. 2001). The microbial biomass nitrogen content was consistent with soil total nitrogen content. Therefore, soil microbial biomass along with soil organic carbon had been recommended as indicators of soil carbon (Carter et al. 1999). The similarity between these forests and Tatachia grassland suggested that the type of vegetation cover, total organic carbon content, and total nitrogen contents played the important roles on microbial biomass.

The microbial biomass carbon/total organic carbon ratios of organic layer, topsoil, and subsoil in grassland were $0.49-1.47,0.25-1.27$, and $0.64-$ $2.43 \%$, respectively. The ratios were lower than tropical forest (1.5-5.3\%) (Luizao et al. 1992) and tropical wet-evergreen forest (4-6\%) (Barbhuiya et al. 2005), similar to subtropical humid forests (0.7-1.7\%) (Maithani et al. 1996), but higher than spruce and hemlock of Tatachia (0.13-1.25\%) (Yang et al. 2003, 2006). However, the ratios of microbial biomass nitrogen/total nitrogen of the organic layer, topsoil and subsoil in grassland were 1.77-2.32, $1.36-1.85$, and $0.87-3.60 \%$, respectively. The ratios were also lower than forest soils (3.4-5.9\%) (Martikainen and Palojarvi 1990) and forest regrowth (7.3-8.3\%) (Maithani et al. 1996), similar to tropical wet-evergreen forest (1.3-1.7\%) (Barbhuiya et al. 2005), but higher than spruce and hemlock of Tatachia (0.13-1.25\%) (Yang et al. 2003, 2006). The alpine ecosystem of Tatachia belonged to acidic type, and the temperature was rather low, so the decomposition rate of litter was low in forest and grassland. The ratios of microbial biomass carbon/ total organic carbon and microbial biomass nitrogen/ total nitrogen were higher in grassland than in other forest ecosystems, indicating that the organic matters in grassland could decompose and be used by microorganisms easier than in the forest. Therefore, the degree of humification was higher in $\mathrm{O}$ layer of grassland than that of forest.

Acidobacteria and Proteobacteria are generally the most numerically dominant phyla in soil, while members of Bacteroidetes and Firmicutes are less common (Dunbar et al. 1999; Chow et al. 2002; Fierer et al. 2005). In this study, we also found Proteobacteria and Acidobacteria to be dominant. Members of $\alpha$ Proteobacteria were the most abundant bacteria in $16 \mathrm{~S}$ rDNA clone libraries derived from Long-Term Soil Productivity (LTSP) forest soil from British Columbia, Canada (Chow et al. 2002), Australian forest soils (Stackebrandt et al. 1993), Scotland grassland rhizosphere soil (McCaig et al. 1999), and fertilizer-applied soil (Toyota and Kuninaga 2006). Members of Acidobacteria were the most abundant in the clone libraries from Arizona pinyon pine rhizosphere and bulk soils (Dunbar et al. 1999), and in desert, prairie, and forest soils (Fierer et al. 2005).

Tatachia grassland soil has an acidic $\mathrm{pH}$, also implying the existence of certain acidophilic bacteria. Despite the effectiveness of culture-independent methods, such as SSU rRNA or rDNA analyzes, microorganisms from these natural habitats must be cultivated to understand their roles in environmental processes and for novel commercially important 
microbes. Moreover, identification of these unclassified group may result in complex diversity. Bacterial species can be identified by generating clone libraries of the $16 \mathrm{~S}$ rDNA followed by sequencing and comparison with databases containing thousands of ribosomal sequences to allow a phylogenetic affiliation to cultured, as well as uncultured microorganisms (Maidak et al. 1999; Ranjard et al. 2000). These techniques have proven to be very suitable for comparative fingerprinting of soil samples (Watanabe et al. 2004). The library of diverse $16 \mathrm{~S}$ rRNA genes from Tatachia grassland soils can be used to construct special DNA primers and probes to target bacterial groups of interest, which gives an opportunity to investigate the relationship between soil bacterial communities and grassland ecosystem in Tatachia forest.

In conclusion, Tatachia grassland soils were weakly acidic and the microbial populations were characterized by high numbers of bacteria, followed by fungi and actinomycetes. The microbial communities were significantly different between topsoil and subsoil. The microbial populations, microbial biomass, and DNA contents were higher in topsoil than those in subsoil. The ratios of cellulolytic microbes to total culturable bacteria count were high due to the heavy coverage of organic matter lying on the soil surface. There was a positive correlation between microbial populations and microbial biomass carbon. The microbial biomass varied with the soil properties and depths. Proteobacteria, Acidobacteria, Actinobacteria, Bacteroidetes, Chloroflexi, Firmicutes, candidate division TM1, candidate division TM7, Gammatimonadetes, and Verrucomicrobia were identified in grassland soils. Members of Proteobacteria (44.4\%) and Acidobacteria (33.3\%) dominated the clone libraries.

Acknowledgements The authors thank Mr. I-Chu Chen for his helpful assistance in sampling, Miss Chia-Bei Wei for her technical assistance, and National Science Council of Taiwan for financial support (NSC 91-2621-B002-014, NSC 92-2621-B002007, NSC 93-2621-B002-005 and NSC 94-2313-B002-090).

\section{References}

Allen, A. S., \& Schlesinger, W. H. (2004). Nutrient limitations to soil microbial biomass and activity in loblolly pine forests. Soil Biology and Biochemistry, 36, 581-589.
Barbhuiya, A. R., Arunachalam, A., Pandey, H. N., Arunachalam, K., Khan, M. L., \& Nath, P. C. (2005). Dynamics of soil microbial biomass $\mathrm{C}, \mathrm{N}$ and $\mathrm{P}$ in disturbed and undisturbed stands of a tropical wet-evergreen forest. European Journal of Soil Biology, 40, 113-121.

Berg, M. P., Kniese, J. P., \& Verhoef, H. A. (1998). Dynamic and stratification of bacteria and fungi in the organic layers of a scots pine forest soil. Biology and Fertility of Soils, 26, 313-322.

Bradley, R. L., \& Fyles, J. W. (1995). Growth of paper birch (Betula papyrifera) seedings increases soil available C and microbial acquisition of soil nutrients. Soil Biology and Biochemistry, 27, 1565-1571.

Brookes, P. C., Landman, A., Pruden, G., \& Jenkinson, D. S. (1985). Chloroform fumigation and the release of soil nitrogen: A rapid direct extraction method to measure microbial biomass nitrogen in soil. Soil Biology and Biochemistry, 17, 837-842.

Carter, M. R., Gregorich, E. G., Angers, D. A., Beare, M. H., Sparling, G. P., Wardle, D. A., \& Voroney, R. P. (1999). Interpretation of microbial biomass measurements for soil quality assessment in humid temperate regions. Canadian Journal of Soil Science, 79, 507-520.

Chang, C. H., Hsieh, C. Y., \& Yang, S. S. (2001). Effect of cultural media on the phosphate-solubilizing activity of thermo-tolerant microbes. Journal of the Biomass Energy Society of China, 20, 79-90.

Chen, W. S., \& Yang, S. S. (2000). Organic acid contents in Tatachia forest soils. Journal of the Experimental Forestry, National Taiwan University, 14, 99-108.

Chow, M. L., Radomski, C. C., McDermott, J. M., Davies, J., \& Axelrood, P. E. (2002). Molecular characterization of bacterial diversity in Lodgepole pine (Pinus contorta) rhizosphere soils from British Columbia forest soils differing in disturbance and geographic source. FEMS Microbiology Ecology, 42, 347-357.

de Boer, W., Tietema, A., Gunnewick, P. J. A. K., \& Laanbroek, H. J. (1992). The chemolithotrophic ammoniumoxidizing community in a nitrogen-saturated acid forest soil in relation to $\mathrm{pH}-$ dependent nitrifying activity. Soil Biology and Biochemistry, 24, 229-234.

Dunbar, J., Takala, S., Barns, S. M., Davis, J. A., \& Kuske, C. R. (1999). Levels of bacterial community diversity in four arid soils compared by cultivation and 16S rRNA gene cloning. Applied and Environmental Microbiology, 65, 1662-1669.

Fierer. N., Jackson, J. A., Vilgalys, R., \& Jackson R. B. (2005). Assessment of soil microbial community structure by use of taxon-specific quantitative PCR assays. Applied and Environmental Microbiology, 71, 4117-4120.

Finlay, B. J. (2002). Global dispersal of free-living microbial eukaryote species. Science, 296, 1061-1063.

Fisk, M. C., Ruether, K. F., \& Yavitt, J. B. (2003). Microbial activity and functional composition among northern peatland ecosystems. Soil Biology and Biochemistry, 35, 591-602.

Garten, C. T. Jr. (2004). Potential net soil N mineralization and decomposition of glycine- ${ }^{13} \mathrm{C}$ in forest soils along an elevation gradient. Soil Biology and Biochemistry, 36, 1491-1496. 
Grayston, S. J., Vaughan, D., \& Jones, D. (1996). Rhizosphere carbon flow in trees, in comparison with annual plants: The importance of root exudation and its impact on microbial activity and nutrient availability. Applied Soil Ecology, 5, 29-56.

Hedlund, K. (2002). Soil microbial community structure in relation to vegetation management on former agricultural land. Soil Biology and Biochemistry, 34, 1299-1307.

Heyndrickx, M., Vaterin, L., Vandamme, P., Kersters, K., \& De Vos, P. (1996). Applicability of combined amplified ribosomal DNA restriction analysis (ARDRA) patterns in bacterial phylogeny and taxonomy. Journal of Microbiological Methods, 26, 247-259.

Imberger, K. T., \& Chiu, C. Y. (2001). Spatial changes of soil fungal and bacterial biomass from a sub-alpine coniferous forest to grassland in a humid, sub-tropical region. Biology and Fertility of Soils, 33, 105-110.

Joergensen, R. G., Brooks, P. C., \& Jenkinson, D. S. (1990). Survival of the soil biomass at elevated temperatures. Soil Biology and Biochemistry, 22, 1129-1139.

Krsek, M., \& Wellington, E. M. H. (1999). Comparison of different methods for the isolation and purification of total community DNA from soil. Journal of Microbiological Methods, 39, 1-16.

Luizao, R. C. C., Bonde, T. A., \& Rosswall, T. (1992). Seasonal variation of soil microbial biomass-the effect of clear felling in a tropical rain forest and establishment of pasture in the Central Amazon. Soil Biology and Biochemistry, 24, 805-813.

Maidak, B. L., Cole, J. R., Parker C. T. Jr., Garrity, G. M., Larsen, N., Li, B., Lilbum, T. G., McCaughey, M. J., Olsen, G. J., Overbeek, R., Pramanik, S., Schmidt, T. M., Tiedje, J. M., \& Woese, C. R. (1999). A new version of the RDP (Ribosomal Database Project). Nucleic Acids Research, 27, 171-173.

Maithani, K., Tripathi, R. S., Arunachalam, A., \& Pandey, H. N. (1996). Seasonal dynamics of microbial biomass C, N and $\mathrm{P}$ during regrowth of a disturbed subtropical humid forest in northeast India. Applied Soil Ecology, 4, 31-37.

Mandels, M., Mrdeiro, J. E., Andreotti, R. E., \& Bisset, F. H. (1981). Evaluation of cellulose culture filtrates under use conditions. Biotechnology and Bioengineering, 23, 20092026.

Martikainen, P. J., \& Palojarvi, A. (1990). Evaluation of the fumigation extraction method for determination of microbial $\mathrm{C}$ and $\mathrm{N}$ in a range of forest soils. Soil Biology and Biochemistry, 27, 797-802.

McCaig, A. E., Glover, L. A., \& Prosser, J. I. (1999). Molecular analysis of bacterial community structure and diversity in unimproved and improved upland grass pastures. Applied and Environmental Microbiology, 65, 1721-1730.

Miethling, R., Wieland, G., Backhaus, H., \& Tebbe, C. C. (2000). Variation of microbial rhizosphere communities in response to crop species, soil origin, and inoculation with Sinorhizobium meliloti L 33. Microbial Ecology, 40, 43-56.

Nannipieri, P., Ascher, J., Ceccherini, M. T., Landi, L., Pietramellara, G., \& Renella, G. (2003). Microbial diversity and soil functions. European Journal of Soil Science, 54, $655-670$.
Nelson, D. W., \& Sommers, L. E. (1982). Total carbon, organic carbon and organic matter. In A. L. Page (Ed.), Methods of soil analysis: Part 2. Chemical and microbiological properties (2nd ed., pp. 539-580). Wisconsin: American Society of Agronomy.

Priha, O., Grayston, S. J., Hiukka, R., Pennanen, T., \& Smolander, A. (2001). Microbial community structure and characteristics of the organic matter in soils under Pinus sylvestris, Picea abies and Betula pendula at two forest sites. Biology and Fertility of Soils, 33, 17-24.

Raghubanshi, A. S. (1991). Dynamics of soil biomass C, N, and $\mathrm{P}$ in a dry tropical forest in India. Biology and Fertility of Soils, 12, 55-59.

Ranjard, L., Poly, F., \& Nazaret, S. (2000). Monitoring complex bacterial communities using culture-independent molecular techniques: Application to soil environment. Research in Microbiology, 151, 167-177.

SAS Institute. (2002). SAS/STAT User's guide, Release 6.03. NC: SAS Institute.

Soil Survey Staff. (2003). Keys to soil taxonomy (9th ed.). Blacksburg: United States Department of Agriculture, Soil Conservation Service. http://www.soils.usda.gov/ technical/classification/tax_keys/.

Srivastava, S. C., \& Singh, J. S. (1988). Carbon and phosphorus in the soil biomass of some tropical soils of India. Soil Biology and Biochemistry, 20, 743-747.

Stackebrandt, E., Liesack, W., \& Goebel, B. M. (1993). Bacterial diversity in a soil sample from a subtropical Australian environment as determined by $16 \mathrm{~S}$ rDNA analysis. The Federation of American Societies for Experimental Biology, 7, 232-236.

Tietema, A., \& Wessel, W. W. (1994). Microbial activity and leaching during initial oak leaf litter decomposition. Biology and Fertility of Soils, 18, 49-54.

Torsvik, V., Sorheim, R., \& Goksoyr, J. (1996). Total bacterial diversity in soil and sediment communities-a review. Journal of Industrial Microbiology, 17, 170-178.

Toyota, K., \& Kuninaga, S. (2006). Comparison of soil microbial community between soils amended with or without farmyard manure. Applied Soil Ecology, 33, 39-48.

Treves D. S., Xia, B., Zhou, J., \& Tiedje, J. M. (2003). A twospecies test of the hypothesis that spatial isolation influences microbial diversity in soil. Microbial Ecology, 45, 20-28.

Tsai, S. H., Selvam, A. \& Yang, S. S. (2007). Microbial diversity of topographical gradient profiles in Fushan forest soils of Taiwan. Ecological Research (in press). DOI 10.1007/s11284-006-0323.2.

Vance, E. D., Brookes, P. C., \& Jenkinson, D. S. (1987). An extraction method for measuring soil microbial C. Soil Biology and Biochemistry, 19, 703-707.

Watanabe, T., Aasakawa, S., Nakamura, A., Nagaoka, K., \& Kimura, M. (2004). DGGE method for analyzing $16 \mathrm{~S}$ rDNA of methanogenic archaeal community in paddy field soil. FEMS Microbiology Letters, 232, 153-163.

Wu, J., Joergensen, R. G., Pommerening, B., Chaussod, R., \& Brookes, P. C. (1990). Measurement of soil microbial biomass $\mathrm{C}$ by fumigation extraction-an autoclaved procedure. Soil Biology and Biochemistry, 22, 1167-1169. 
Yang, C. K., \& Yang, S. S. (2001). Microbial ecology of soils surrounding nuclear and thermal power plants in Taiwan. Environment International, 26, 315-322.

Yang, S. S., Chang, H. L., Wei, C. B., \& Lin, H. C. (1991). Reduce waste production with modified Kjeldahl method for nitrogen measurement. Journal of the Biomass Energy Society of China, 10, 147-155.

Yang, S. S., Fan, H. Y., Yang, C. K., \& Lin, I. C. (2003). Microbial population of spruce soil in Tatachia mountain of Taiwan. Chemosphere, 52, 1489-1498.

Yang, S. S., Lai, C. M., Sun, L. Y., Luo, Y. C., Fan, H. Y., Yang, C. K., \& Wei, C. B. (1998a). Microbial ecology of Tatachia mountain soil. Journal of the Chinese Agricultural Chemical Society, 36, 229-238.

Yang, S. S., Lin, Y. C., Yang, C. K., Chang, E. H., \& Wei, C. B. (1999). Microbial ecology of Hsieh-Ho thermal power plant and its surrounding area. Journal of Microbiology, Immunology and Infection, 32, 269-277.

Yang, S. S., Sun, R. Y., Yang, C. K., Wei, C. B., Huang, R. Y., \& Hsu, W. F. (1998b). Microbial population at nuclear power plant No. 2 and its surrounding areas. Journal of Environmental Protection Society of ROC, 21, 144-158.

Yang, S. S., Tsai, S. H., Fan, H. Y., Yang, C. K., Huang, W. L., \& Cho, S. T. (2006). Microbial population of hemlock soil in Tatachia mountain of Taiwan. Journal of Microbiology, Immunology and Infection, 39, 195-205.

Zhou, J. Z., Xia, B. C., Treves, D. S., Wu, L. Y., Marsh, T. L., O’Neill, R.V., Palumbo A.V., \& Tiedje, J. M. (2002). Spatial and resource factors influencing high microbial diversity in soil. Applied and Environmental Microbiology, 68, 326-334. 